\title{
POLA PEMBAGIAN KERJA DAN KONTRIBUSI GENDER TERHADAP PENDAPATAN KELUARGA: STUDI KASUS RUMAH TANGGA NELAYAN DI DESA BATANJUNG KABUPATEN KAPUAS
}

\author{
Hikmah, Maharani Yulisti dan Zahri Nasution' \\ 1 Peneliti pada Balai Besar Riset Sosial Ekonomi Kelautan dan Perikanan \\ JI. KS. Tubun Petamburan VI, Jakarta 10260 \\ Telp. 021 53650162/Fax. 02153650159
}

\begin{abstract}
ABSTRAK
Penelitian ini dilaksanakan tahun 2007 dengan tujuan memberikan gambaran pola pembagian kerja dan kontribusi gender terhadap pendapatan rumah tangga serta strategi pemberdayaan gender dalam rangka menopang peningkatan pendapatan rumah tangga nelayan. Metode pendekatan secara kualitatif dalam bentuk studi kasus digunakan dalam penelitian ini. Metode analisis yang digunakan adalah metode analisis deskriptif. Hasil penelitian menggambarkan bahwa pola pembagian kerja dan curahan waktu dalam aktivitas produktif pada rumah tangga nelayan di desa Batanjung Kabupaten Kapuas didominasi oleh perempuan. Sementara laki-laki umumnya terlibat sebagai tenaga pembantu saja. Pola pembagian kerja pada aktivitas produktif lebih didominasi oleh laki-laki. Namun demikian, istri juga terlibat dalam aktivitas penangkapan di perairan umum (rawa dan sungai) yang lokasinya dekat dengan pemukiman mereka. Istri nelayan memiliki kontribusi yang cukup besar dan memegang peranan penting dalam ekonomi rumah tangga. Meskipun jika dilihat dari curahan waktu produktifnya, istri nelayan jauh lebih sedikit dibandingkan suami. Namun demikian, tetap saja kedudukan istri dalam kegiatan produktif hanya dianggap membantu suami untuk menambah pendapatan keluarga.
\end{abstract}

Kata Kunci: Rumah Tangga Nelayan, Kontribusi Gender, Pendapatan

\section{Abstract: Work Share Pattern and Gender Contribution to Fisher's Household Income: Case Study of Fisher's Household in Batanjung Village, Kapuas District. By Hikmah, Maharani Yulisti and Zahri Nasution.}

This research has been executed in 2007 aiming to give the description concerning with work share pattern and gender contribution to household income, and also to give description of gender empowerment strategy in effort to support increasing income of fisher's household. Descriptive analysis was used in this research. Results show that work share pattern and time spent in reproductive activities at fisher's household in Batanjung village, Kapuas district was dominated by women, whereas men generally were involved as assistant workers. Work share pattern at productive activities was dominated by men. But, women were also involved in fishing activities at inland fisheries (river and swamp) where the fishing ground nearby with their resident. Fisher's wife had a big contribution and hold important role in household economy. Even though wife had more time to spend on productive activities than husband, but wife's position in productive activities was still considered to be an assistant of husband in the household income.

Keywords: Fishers, Gender, Income 


\section{PENDAHULUAN}

Ketidakberdayaan nelayan terkait dengan tingkat pendapatan yang sangat rendah, menuntut peningkatan peran kaum perempuan (istri) untuk menopang ekonomi keluarga melalui keterlibatannya dalam pencarian nafkah tambahan. Dari waktu ke waktu, kontribusi tenaga kerja perempuan terhadap rumah tangga nelayan meningkat secara signifikan, dan berkembang menjadi salah satu mata rantai yang tidak dapat diabaikan dalam ekonomi nelayan, terutama untuk kalangan masyarakat nelayan strata bawah. Saat ini, sebagian besar istri nelayan tidak hanya bergelut dalam urusan domestik rumah tangga, melainkan juga memainkan fungsi-fungsi ekonomi penting dalam industri perikanan. Tidak hanya pada usaha-usaha pengolahan sebagaimana terjadi pada masamasa sebelumnnya tetapi juga termasuk segmen-segmen yang secara tradisi identik dengan usaha kaum pria, misalnya kegiatan penangkapan di perairan dangkal, dan kegiatan jasa dan perdagangan.

Selama ini, peran dan kontribusi perempuan (istri) nelayan terhadap ekonomi keluarga cukup memegang peranan penting. Namun demikian, peran tersebut belum didukung sepenuhnya oleh kebijakan pemerintah yang memihak kepada mereka. Sejauh ini, pendekatan pembangunan belum secara khusus mempertimbangkan manfaat pembangunan secara adil terhadap perempuan dan laki-laki, sehingga hal tersebut turut memberi kontribusi timbulnya ketidaksetaraan dan ketidakadilan gender. Bentuk-bentuk ketidaksetaraan dan ketidakadilan gender yang dikenal dengan kesenjangan gender (gender gap) pada gilirannya menimbulkan permasalahan gender (gender issues) (Kementerian Pemberdayaan Perempuan, 2002).

Pembangunan yang bertujuan untuk meningkatkan kualitas manusia seharusnya memperhatikan kondisi wanita maupun pria atau bersifat gender sensitive. Peran wanita dapat dioptimalkan apabila faktor penghambat yang melingkupinya dapat diidentifikasi dengan baik. Ketika seorang perempuan berperan ganda untuk tetap menjaga kelangsungan kehidupan rumah tangganya, maka ia berpeluang untuk memperkuat posisi mereka dalam konteks ekonomi yang lebih besar. Apabila hal ini dapat terjadi, maka keberdayaan nelayan (suami) yang ditopangnya dapat semakin ditingkatkan.

Tulisan ini bertujuan untuk memberikan gambaran tentang pola pembagian kerja dan kontribusi gender terhadap pendapatan rumah tangga serta strategi pemberdayaan gender dalam rangka menopang upaya peningkatan pendapatan rumah tangga nelayan. Tulisan ini diharapkan dapat memberikan masukan bagi pengambil kebijakan dan sebagai langkah awal untuk melakukan strategi kebijakan yang mengarah kepada kebijakan-kebijakan pengembangan dan pemberdayaan.

\section{METODOLOGI}

\section{Kerangka Pemikiran}

Gender menjadi persoalan ketika nilainilai yang terkandung dalam ketentuan gender tersebut menghambat seseorang untuk mempunyai akses dan kontrol terhadap sumberdaya dan hasil-hasilnya. Sebagai contoh, dominasi ekonomi oleh kaum laki-laki merupakan terjemahan dari 'kekuasaan lakilaki' telah menggiring perempuan ke dalam kedudukannya sebagai orang kedua yang kurang begitu penting dibandingkan laki-laki. Dalam anggapan laki-laki pencari nafkah utama atau laki-laki sebagai pekerja produktif sangat dominan meskipun kadang-kadang tidak demikian. Sebagian besar kaum laki-laki beranggapan bahwa dalam keluarga mereka memegang peran sebagai penghasil pendapatan utama dan penentu segala keputusan. Hal ini tetap berlangsung, meskipun dalam keadaan dimana adanya pengangguran laki-laki tinggi dan kerja produktif perempuan sesungguhnya memberikan hasil utama. 
Hal serupa juga dirasakan oleh sebagian perempuan nelayan. Umumnya laki-laki hanya beraktivitas di sektor publik sedangkan perempuan memiliki peran ganda yaitu aktivitas domestik dan publik. Kusnadi (2001) menyatakan bahwa dalam masyarakat nelayan terdapat pola pembagian kerja secara seksual yang sangat kuat pengaruhnya secara kultural, yaitu "laut adalah wilayah laki-laki, sedangkan darat adalah wilayah perempuan". Karena alasan ekonomi, yaitu penghasilan suami tidak mencukupi kebutuhan keluarga, maka umum terjadi dalam masyarakat nelayan, istri harus bekerja untuk ikut menambah penghasilan keluarga.

Pada masyarakat nelayan di berbagai wilayah, ditemukan kaum perempuan yang dikenal sebagai pekerja ulet dalam berbagai aktivitas untuk menunjang perekonomian keluarga, khususnya aktivitas yang langsung berhubungan dengan persiapan produksi, pemrosesan dan pemasaran hasil perikanan. Saruan (2000) juga menegaskan hal yang serupa yaitu wanita nelayan dominan bekerja dalam bidang industri pengolahan hasil ikan, perdagangan hasil penangkapan ikan dan persiapan operasi penangkapan, sedangkan laki-laki bekerja dalam bidang operasi penangkapan.

\section{Metode penelitian}

Metode yang digunakan dalam penelitian ini bersifat kualitatif dengan mengambil bentuk studi kasus di Desa Batanjung Kabupaten Kapuas sebagai sasaran studi dan membatasi pada suatu komunitas rumah tangga nelayan. Menurut Yin (2002) studi kasus merupakan metode yang dianggap tepat untuk menjawab pertanyaan "bagaimana, mengapa" serta tepat bagi penelitian yang hanya memiliki peluang kecil sekali atau tidak mempunyai peluang sama sekali untuk melakukan kontrol terhadap peristiwa tersebut.

Batasan unit analisisnya adalah rumah tangga nelayan yang meliputi sejumlah orang atau kasus (peristiwa lokal), sehingga membatasi peluang untuk generalisasi, namun memungkinkan pemahaman yang mendalam tentang peristiwa atau gejala sosial tertentu. Tujuan penelitian kualitatif adalah pertama untuk mengetahui apa/bagaimana peristiwa atau gejala sosial yang sedang terjadi (eksploratif); kedua, untuk menerangkan mengapa sesuatu peristiwa atau gejala sosial terjadi (Sitorus, 1998).

\section{Pengumpulan Data}

Dalam penelitian ini data yang dikumpulkan berupa data primer dan data sekunder. Data sekunder mencakup informasi yang berkaitan dengan gambaran fisik daerah penelitian serta keragaan sosial ekonomi daerah penelitian diperoleh dari dokumen atau arsip tertulis, laporan hasil penelitian dan publikasi lainnya. Lembaga yang dikunjungi adalah Dinas Perikanan dan Kelautan Kabupaten Kapuas dan Kantor Kepala Desa Batanjung.

Pengumpulan data primer dilakukan denga dua cara:

1. Melakukan diskusi kelompok (Focus group discussion). Diskusi ini dilakukan dua tahap yaitu: Pertama, diskusi yang diikuti oleh laki-laki yang bertujuan untuk mendapatkan masukan tentang berbagai hal seperti tanggapan mereka tentang nilai gender dan peran gender dalam masyarakat. Kedua, diskusi yang diikuti oleh perempuan, dimaksudkan untuk menggali lebih dalam tentang makna kerja bagi mereka, demikian juga tentang nilai dan peranan gender dalam rumah tangga dan masyarakat.

2. Melakukan wawancara terstruktur kepada 30 orang responden diambil secara acak dibantu dengan kuesioner terpola yang sudah disiapkan terlebih dahulu sesuai dengan tujuan yang ingin dicapai dalam penelitian ini. Di samping itu dilakukan juga observasi lapang guna mengetahui kondisi masyarakat nelayan setempat terutama terkait dengan perumahan dan lingkungannya serta pola pemukiman. 


\section{Pengolahan dan Analisis Data}

Pengolahan data yang sifatnya kuantitatif hasil wawancara terstruktur dilakukan dengan cara tabulasi silang, dan prosentase, serta disajikan dalam bentuk tabel. Analisis data secara kualitatif dilakukan melalui tiga jalur analisis: reduksi data, penyajian data dan penarikan kesimpulan (Miles dan Hubeman, 1992). Data kualitatif digunakan untuk menambah memperkaya pemahaman tentang isu-isu pokok penelitian. Dengan demikian akan diperoleh gambaran yang utuh terkait dengan karakteristik sosial ekonomi dan budaya masyarakat nelayan, pola pembagian kerja dan curahan waktu serta kontribusi gender terhadap pendapatan rumah tangga nelayan. Sebagai studi kasus, kesimpulan yang dihasilkan dari penelitian ini hanya terbatas pada komunitas yang diteliti.

\section{HASILDAN PEMBAHASAN}

\section{Karakteristik Sosial Ekonomi dan Budaya Masyarakat Nelayan}

\section{Stratifikasi Sosial}

Salah satu penyebab kurang berkembangnya sektor perikanan di desa Batanjung adalah homogenitas pekerjaan yang didominasi oleh kegiatan yang tergolong prakapitalis. Ukuran mesin yang dimiliki rata-rata 5 GT dan memiliki jangkauan terbatas, bahkan masih ada nelayan yang menggunakan sampan (perahu tanpa motor) untuk menangkap ikan. Kondisi ini menggambarkan aktivitas sektor perikanan di desa Batanjung masih bersifat artisanal dan subsisten.

Dalam kehidupan masyarakat desa terdapat tokoh-tokoh informal di luar pemimpin formal (kepala desa) seperti tokoh agama dan lainnya. Stratifikasi sosial terlihat dari adanya pengelompokan masyarakat berdasarkan teknologi penangkapan ikan. Pengelompokan tersebut antara lain adalah kelompok nelayan sungkur dan nelayan lampara. Nama kelompok tersebut berasal dari jenis alat tangkap sungkur dan lampara. Kelompok nelayan sungkur identik dengan modal kecil, sedangkan kelompok nelayan lampara identik dengan nelayan yang mempunyai modal besar.

Dari segi ekonomi, stratifikasi terlihat berdasarkan golongan atas dan golongan bawah. Namun perbedaan ini tidak dapat dicirikan secara fisik karena kebiasaan hidup yang sama dengan golongan bawah. Strata atas mencakup golongan pemilik kapal, pedagang dan pemilik toko. Sedangkan strata bawah mencakup nelayan pekerja dan pemilik warung. Stratifikasi ini terlihat dari cara pandang masyarakat terhadap diri mereka dan diri orang lain. Namun perbedaan status ini tidak terlihat dalam tingkah laku bermasyarakat. Interaksi antara nelayan pekerja dengan nelayan pemilik terjalin sebagaimana layaknya tanpa ada perbedaan perlakuan dari masing-masing pihak.

\section{Aktivitas Ekonomi}

Pada bidang ekonomi, sampai saat ini pola tata niaga hasil perikanan masih langsung dilakukan di perairan oleh nelayan begitu selesai beroperasi di laut. Hal ini menyebabkan kekuatan tawar dari nelayan kurang kuat karena tidak ada pedagang lainnya (monopoli). Karena transaksi ini terjadi di perairan, maka tidak ada pemasukan (retribusi) bagi pemerintah daerah sebagai pendapatan asli daerah dari sektor perikanan laut. Tempat pendaratan ikan yang diharapkan dapat mengatasi sistem transaksi di laut ternyata belum digunakan oleh nelayan sebagaimana yang diharapkan. Hal ini juga mengakibatkan akses nelayan terhadap konsumen akhir sangat kurang (nelayan tidak mengetahui informasi jenis ikan yang diminati dan berapa harga ikan di tingkat konsumen akhir).

Dalam hal permodalan nelayan, pengoperasian lampara dan sungkur hanya dilakukan oleh sebagian nelayan yang memiliki modal kuat. Sementara yang bermodal lemah hanya mengoperasikan alat 
tangkap yang sederhana dan minim seperti pancing, bubu dan rengge, sehingga pendapatannya sangat rendah dibandingkan dengan nelayan lampara atau sungkur. Nelayan bermodal lemah ini lebih bersifat subsisten, lemah dalam mencari alternatif cara untuk memperoleh modal, tidak memperhitungkan keuntungan, dan lebih membutuhkan cash money (hasil tangkapan harus segera dijual untuk memenuhi kebutuhan hidup sehari-hari, walaupun harga ikan rendah).

Sementara itu lembaga ekonomi yang diharapkan dapat menunjang ekonomi nelayan seperti koperasi belum berfungsi dengan optimal untuk memenuhi kebutuhan nelayan yang bermodal lemah. Lembaga ekonomi perikanan mikro Mitra Mina sebagai lembaga yang dipercaya untuk menyalurkan kredit bergulir kurang mampu untuk memenuhi, menyalurkan dan mengendalikan modal kredit yang diajukan oleh nelayan.

\section{Kearifan Lokal dalam Pengelolaan Sumberdaya Perikanan}

Masyarakat di desa Batanjung dan Desa Cemara Labat tidak mengenal klaim atas kepemilikan laut sehingga dikatakan perairan laut merupakan sumberdaya yang bersifat milik bersama (common property). Pemahaman yang dianut masyarakat di daerah ini adalah 'laut merupakan milik bersama dan boleh dimanfaatkan oleh siapa saja', sehingga nelayan manapun boleh menangkap ikan dimana saja. Masyarakat desa Batanjung memahaminya sebagai azas kesetaraan dalam pemanfaatan sumberdaya lokal.

Beberapa kesepahaman masyarakat yang terbentuk ikut mempengaruhi pemanfaatan sumberdaya laut di daerah ini. Kesepahaman ini selanjutnya disebut sebagai kearifan lokal yang mengatur tentang pemanfaatan sumberdaya laut. Disebut kearifan lokal karena kesepahaman tersebut terbentuk secara konvensional dan tidak dilembagakan dalam sebuah lembaga tradisional.
Kearifan lokal mampu mencegah terjadinya perselisihan antar nelayan. Kearifan lokal tersebut antara lain: pertama, tidak boleh melaut pada hari jumat. Hari jumat merupakan hari istirahat bagi nelayan. Alasan masyarakat tidak menangkap ikan pada hari jumat adalah supaya nelayan dapat melakukan ibadah shalat jumat dengan khusyuk. Kebiasaan masyarakat ini berpengaruh positif bagi kegiatan perikanan di wilayah ini. Selain tidak menangkap ikan, waktu yang ada digunakan untuk kegiatan perawatan dan perbaikan alat tangkap seperti merajut jaring, mengecat perahu, memperbaiki bagian perahu yang rusak dan lain sebagainya.

Kedua, larangan menggunakan potassium dan bom. Pada dasarnya nelayan sudah memahami alat-alat tangkap yang dapat merusak lingkungan. Oleh karena itu sebagian besar nelayan lokal sangat menentang penggunaan potassium dan bom. Bagi nelayan manapun baik lokal maupun nelayan luar tidak diperkenankan menggunakan bahan-bahan tersebut. Apabila ada yang sembunyi-sembunyi menggunakan bahan tersebut akan mendapatkan teguran.

\section{Pola Pembagian Kerja dan Curahan Waktu}

Menurut Stirrat (1989) dalam Kusnadi (2001), pola aktivitas di kalangan masyarakat nelayan tidak terlepas dari sistem pembagian kerja secara seksual yang berlangsung dalam masyarakat yang bersangkutan. Istilah pembagian kerja merujuk pada pola peranan dari suami dan istri dalam keluarga untuk melakukan pekerjaan-pekerjaan tertentu yang saling berbeda. Sedangkan Hubeis (2000) menyebutkan bahwa pembagian kerja dalam perspektif gender mengacu pada cara-cara dimana semua jenis-jenis pekerjaan (reproduktif, produktif dan sosial) dibagi antara pria dan wanita serta bagaimana pekerjaan tersebut dinilai dan dihargai secara kultural dalam masyarakat tertentu. Pekerjaan reproduktif atau domestik adalah kegiatan yang terkait dengan pemeliharaan sumberdaya manusia dan tugas-tugas kerumahtanggaan seperti menyiapkan 
makanan, berbelanja, mengasuh dan mendidik anak. Pekerjaan produktif menyangkut segala pekerjaan yang bertujuan menghasilkan barang dan jasa untuk dikonsumsi sendiri atau diperdagangkan. Pekerjaan sosial adalah pekerjaan atau aktivitas yang terkait dengan aspek status kekuasaan atau kewajiban bagi seseorang yang terbentuk secara kultural pada struktur masyarakat di mana ia tinggal.

Pola pembagian kerja dan curahan waktu dalam aktivitas domestik pada rumah tangga nelayan di Desa Batanjung Kabupaten Kapuas tidak menampilkan perbedaan atau kekhasan dibanding pola yang sudah dikenal di pedesaan. Aktivitas domestik yaitu kegiatan yang menjamin kelangsungan hidup manusia dan keluarga berupa ragam jenis pekerjaan rumah tangga dan pengasuhan anak adalah tanggug jawab perempuan. Laki-laki umumnya terlibat sebagai tenaga pembantu saja.

Pada Tabel 1 terlihat bahwa pola pembagian kerja domestik masih didominasi oleh perempuan. Dalam pekerjaan yang membutuhkan curahan tenaga yang cukup besar, misalnya mengambil air didominasi oleh laki-laki. Hal ini terkait dengan lokasi sumber air (terutama air tawar untuk keperluan minum dan memasak) yang jauh dari lokasi pemukiman.

Pembagian kerja pada aktivitas produktif lebih didominasi oleh laki-laki. Namun demikian, istri juga terlibat dalam aktivitas penangkapan. Hanya saja aktivitas penangkapan yang dilakukan oleh perempuan tidak dilakukan di laut, melainkan di perairan umum (rawa dan sungai) yang lokasinya dekat dengan pemukiman mereka. Alat tangkap yang digunakan adalah rengge, bubu, dan

Tabel 1. Pola Pembagian Kerja dalam Akvitas Domestik di Desa Batanjung, Kabupaten Kapuas, Tahun 2007.

Table 1. Work Share Pattern on Domestic Activities in Batanjung Village, Kapuas District, 2007.

\begin{tabular}{|c|c|c|}
\hline No & $\begin{array}{l}\text { Jenis Pekerjaan/ } \\
\text { Type of Work }\end{array}$ & $\begin{array}{l}\text { Pembagian Kerjal } \\
\text { Work Share }\end{array}$ \\
\hline 1. & Mengambil air/ Taking some freshwater & L\&P (DL) \\
\hline 2. & Memasak/ Cooking & $\mathrm{P}$ \\
\hline 3. & $\begin{array}{l}\text { Mencuci alat rumah tangga/ } \\
\text { Washing household equipment }\end{array}$ & $\mathrm{P}$ \\
\hline 4. & Menyetrika/ Ironing & $\mathrm{P}$ \\
\hline 5. & Belanja/ Shopping & $\mathrm{P}$ \\
\hline 6. & Membersihkan rumah /Cleaning the house & L\&P (DP) \\
\hline \multirow[t]{4}{*}{7.} & $\begin{array}{l}\text { Mengasuh anak/ Taking care of children } \\
\text { a. Memandikan anak/ Taking bath the children }\end{array}$ & $\begin{array}{l}\text { L\&P (DP) } \\
\qquad P\end{array}$ \\
\hline & b. Membantu anak dalam belajar/ Helping the children to learn & L\&P (DP) \\
\hline & c. Memberi makan/Feeding the children & $\mathrm{P}$ \\
\hline & d. Menjaga anak/Taking care of children & L\&P (DP) \\
\hline
\end{tabular}

Sumber:Data Primer Diolah Tahun 2007/ Source:Primary Data Processed, 2007.

Keterangan/ Remark:

$\mathrm{L}=$ Laki-laki/Man;

$\mathrm{P}=$ Perempuan / Woman;

$\mathrm{DL}=$ Dominan Laki-laki/ Dominant of Man;

DP = Dominan Perempuan/ Dominant of Woman 
Tabel 2. Pola Pembagian Kerja dalam Aktivitas Produktif di Desa Batanjung, Kabupaten Kapuas, Tahun 2007.

Table 2. Pattern of Labor Division on Productive Activities in Batanjung Village Kapuas District, 2007.

\begin{tabular}{clc}
\hline No & \multicolumn{1}{c}{$\begin{array}{c}\text { Jenis Pekerjaan/ } \\
\text { Type of Work }\end{array}$} & $\begin{array}{c}\text { PembagianKerja/ } \\
\text { Work Share }\end{array}$ \\
\hline 1. & $\begin{array}{l}\text { Pesiapan perbekalan melaut/ Prepare of capture } \\
\text { 2. }\end{array}$ & Menangkap ikan/ Fish catching \\
3. & Pembongkaran ikan dari kapal/Unloading of fish from ship & L\&P (DL) \\
4. & Penjualan ikan/ Selling of fish & $\mathrm{L}$ \\
5. & Memperbaiki alat tangkap / Repairing the fishing gear & $\mathrm{L} \& \mathrm{DP}$ (D) \\
6. & Memperbaiki kapal/Repairing of ship & $\mathrm{L}$ \\
7. & Membersihkan kapal/ Cleaning of ship & $\mathrm{L}$ \\
8. & Memperbaiki mesin/ Repair of machine & $\mathrm{L}$ \\
9. & Pengolahan ikan/ Processing of fish & L\&P (DP) \\
10. & Menjual ikan hasil olahan/ Selling the fish product & L\&P (DP) \\
\hline
\end{tabular}

Sumber: Data Primer Diolah Tahun 2007/ Source :Primary Data Processed, 2007.

Keterangan/ Remark: $\quad \mathrm{L} \quad=$ Laki-laki/Man;

P = Perempuan / Woman;

$\mathrm{DL} \quad=$ Dominan Laki-laki/ Dominant of Man;

DP = Dominan Perempuan/ Dominant of Woman

lukah. Kegiatan penangkapan dimulai dengan memasang alat tangkap pada sore hari, kemudian alat tersebut diangkat pada pagi harinya. Disamping itu, kegiatan produktif wanita nelayan adalah berdagang. Dalam konteks budaya masyarakat setempat, aktivitas produktif (mencari nafkah untuk keluarga) adalah tanggung jawab laki-laki (suami), sedangkan perempuan (istri) sifatnya hanya membantu saja.

Pada Tabel 3 dapat dilihat perbandingan persentase curahan waktu suami dan istri pada setiap aktivitas/kegiatan. Pada kegiatan produktif curahan waktu suami sebesar 9,98 jam/hari $(41,58 \%)$ dari siklus waktu dalam sehari. Curahan waktu istri pada kegiatan produktif sebesar 3,58 jam/hari $(14,92 \%)$ dari siklus waktu dalam sehari. Pada kegiatan domestik curahan waktu suami lebih sedikit dari pada istri. Hal ini terlihat dari jumlah curahan waktu domestik suami hanya 2,26 $(9,42 \%)$ dari siklus waktu dalam sehari, sedangkan curahan waktu istri pada kegiatan domestik sebesar 10,33 jam/hari (43,04\%) dari siklus dalam sehari. Curahan waktu untuk kegiatan waktu luang dan kebutuhan dasar suami adalah sebesar 6,25 jam/hari $(26,04 \%)$ dalam siklus waktu sehari. Sedangkan curahan waktu untuk kegiatan waktu luang dan kebutuhan dasar istri adalah sebesar 6 jam/hari $(25,00 \%)$ dalam siklus waktu sehari. Untuk aktivitas/kegiatan sosial, curahan waktu suami sebesar 5,51 jam/hari $(22,96 \%)$ dalam siklus waktu sehari dan curahan waktu istri sebesar 4,09 jam/hari (17,04\%) dalam siklus waktu sehari.

Tabel 3 menunjukkan bahwa peran suami pada sektor publik lebih besar dibanding istri, besarnya curahan waktu suami pada aktivitas publik khususnya pada kegiatan produktif menangkap ikan di laut. Sementara itu, peran istri lebih besar pada ruang lingkup domestik seperti mencuci, memasak, mengasuh dan mendampingi anak, dan lain-lain. Sedangkan 
Tabel 3. Curahan Waktu Kegiatan Rumah Tangga Nelayan di Desa Batanjung, Kabupaten Kapuas, Tahun 2007.

Table 3. Time Spent for Fisher's Household Activities at Batanjung Village, Kapuas District, 2007.

\begin{tabular}{|c|c|c|c|c|}
\hline \multirow{2}{*}{$\begin{array}{l}\text { Profil Kegiatan/ } \\
\text { Activities Profile }\end{array}$} & \multicolumn{4}{|c|}{ Curahan Waktu/ Time Spent $(\mathrm{n}=30)$} \\
\hline & $\begin{array}{l}\text { Suami/ } \\
\text { Husband }\end{array}$ & $\%$ & Istri/Wife & $\%$ \\
\hline $\begin{array}{l}\text { Kegiatan produktif (jam/hari)/ } \\
\text { Productive activities (hours/day) }\end{array}$ & 9,98 & 41,58 & 3,58 & 14,92 \\
\hline $\begin{array}{l}\text { Kegiatan domestik (jam/hari)/ } \\
\text { Domestic activities (hours/day) }\end{array}$ & 2,26 & 9,42 & 10,33 & 43,04 \\
\hline $\begin{array}{l}\text { Waktu luang dan kebutuhan dasar keluarga } \\
\text { (jam/hari)/ Leisure and family base needed } \\
\text { (Hours/day) }\end{array}$ & 6,25 & 26,04 & 6,00 & 25,00 \\
\hline $\begin{array}{l}\text { Aktivitas/kegiatan sosial (jam/hari)/ Social } \\
\text { activities (hours/day) }\end{array}$ & 5,51 & 22,96 & 4,09 & 17,04 \\
\hline
\end{tabular}

Sumber: Data Primer Diolah Tahun 2007/ Source:Primary Data Processed, 2007.

curahan waktu istri pada aktivitas publik seperti berdagang, mengolah ikan, dan kegiatan sosial lebih sedikit dibanding suami.

Berdasarkan Tabel diatas tampak jelas terlihat bahwa ketimpangan gender masih sangat kental mewarnai pola pembagian kerja masyarakat nelayan setempat. Ketimpangan gender dalam hal ini adalah istri memiliki peran ganda yaitu sebagai penanggungjawab dalam urusan rumah tangga dan juga membantu suami sebagai pencari nafkah.

Beban berat istri terlihat dari kenyataan bahwa mereka tetap akan bekerja di bidang produktif walaupun mereka juga harus mengerjakan pekerjaan domestik yang menjadi taggung jawabnya. Adapun pekerjaan seperti mengasuh dan merawat anak memang dianggap sebagai kodrat istri di samping pekerjaan dan kegiatan-kegiatan yang kelihatannya tetap menjadi beban istri.

Demikian pula terhadap pendidikan anak, yang lebih diutamakan adalah laki-laki. Karena menurut masyarakat setempat, laki-laki merupakan tulang punggung keluarga dalam mencukupi kebutuhan istri dan anak. Sedangkan anak perempuan nantinya akan mengikuti suaminya. Hal lain yang menyebabkan anak wanita tidak diutamakan pendidikannya adalah karena sarana pendidikan formal yang hanya sampai tingkat SLTP, sedangkan tingkat SLTA harus dilanjutkan ke kota. Para orang tua khawatir akan terjadi apa-apa terhadap anak perempuannya. Menurut anggapan mereka anak perempuan sangat beresiko jika dibiarkan menuntut ilmu di kota. Sedangkan anak laki-laki dianggap tidak terlalu berisiko karena laki-laki tidak akan membawa aib dalam keluarga.

\section{Kontribusi Gender Terhadap Pendapatan Rumah Tangga Nelayan}

Pada Tabel 4 terlihat rata-rata kontribusi suami terhadap pendapatan keluarga nelayan di Desa Batanjung Kabupaten Kapuas sebesar 70,98\% perbulan (Rp. 1.871.290). Sedangkan rata-rata kontribusi isteri nelayan terhadap pendapatan sebesar 29,02\% perbulan (Rp. 765.217).

Sebagai pihak kedua dalam rumah tangga yang bertanggung jawab mencari nafkah, istri nelayan memiliki kontribusi yang cukup besar dan memegang peranan penting dalam ekonomi rumah tangga. Meskipun jika dilihat dari curahan waktu produktif istri nelayan jauh lebih sedikit dibandingkan suami, kontribusinya cukup besar bagi pendapatan keluarga. Namun demikian kedudukan istri 
Tabel4. Kontribusi Gender Terhadap Pendapatan Rumah Tangga Nelayan di Desa Batanjung, Kabupaten Kapuas, Tahun 2007.

Table 4. Gender Contributions to Fisher's Household Income in Batanjung Village, Kapuas District, 2007.

\begin{tabular}{lcc}
\hline $\begin{array}{c}\text { Kontribusi Gender Terhadap Pendapatan } \\
\text { Rumah Tangga / }\end{array}$ & $\begin{array}{c}\text { Pendapatan/ Income } \\
\text { (Rp./ bln)/ (IDR/month) }\end{array}$ & $\begin{array}{c}\text { Kontribusi/ } \\
\text { Contribution } \\
\text { (\%) }\end{array}$ \\
\hline 1. Pendapatan suami/Husband income & 1.871 .290 & 70,98 \\
2. Pendapatan istri / Wife income & 765.217 & 29,02 \\
\hline
\end{tabular}

Sumber: Data Primer Diolah Tahun 2007/ Source: Primary Data Processedat, 2007.

dalam kegiatan produktif tetap saja hanya dianggap membantu suami untuk menambah pendapatan keluarga. Hal ini sependapat dengan Rahardjo (1995) yang menyatakan bahwa pada umumnya peran perempuan secara ekonomi adalah menambah penghasilan keluarga. Karena itu penghasilan tambahan dari aktivitas ekonomi perempuan dapat membantu mengentaskan keluarga dari kemiskinan.

\section{IV.KESIMPULAN DAN IMPLIKAS I KEBIJAKAN}

\section{Kesimpulan}

1. Pola pembagian kerja dan curahan waktu dalam aktivitas domestik pada rumah tangga nelayan di desa Batanjung kabupaten Kapuas didominasi oleh perempuan. Sementara laki-laki umumnya terlibat sebagai tenaga pembantu saja.

\section{Rata-rata Kontribusi Gender Terhadap Pendapatan Keluarga/ Average Of Gender Contribution to Household Income}

Rp. 765.217 $(29 \%)$

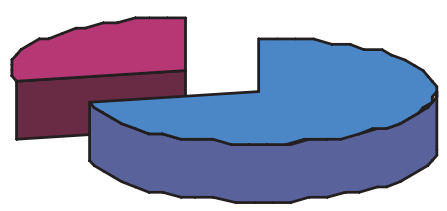

Rp.1.871.290

$(71 \%)$
Rata-rata pendapatan suami/ Average of husband Income

Rata-rata pendapatan Istri/ Average of wife income

Gambar 1. Kontribusi Gender Terhadap Rumah Tangga Nelayan.

Figure 1. Gender Contribution to Household Fisher's Income. 
2. Pola pembagian kerja pada aktivitas produktif lebih didominasi oleh laki-laki. Istri juga terlibat dalam aktivitas penangkapan. Aktivitas penangkapan yang dilakukan perempuan tidak dilakukan di laut, melainkan di perairan umum (rawa dan sungai) yang lokasinya dekat dengan pemukiman mereka.

3. Istri nelayan memiliki kontribusi yang cukup besar dan memegang peranan penting dalam ekonomi rumah tangga. Curahan waktu produktif istri nelayan jauh lebih sedikit dibandingkan suami. Namun demikian, kedudukan istri dalam kegiatan produktif tetap dianggap membantu suami untuk menambah pendapatan keluarga.

4. Terlihat jelas adanya ketimpangan gender baik dilihat dari aspek karakteristik sosial ekonomi dan budaya, pola pembagian kerja dan curahan waktu maupun kontribusi gender terhadap pendapatan rumah tangga nelayan. Ketimpangan gender ini merupakan permasalahan yang mendasar bagi pembangunan pemberdayaan masyarakat nelayan.

\section{Implikasi Kebijakan}

Strategi kebijakan yang dapat dipertimbangkan dalam peningkatan ekonomi rumah tangga nelayan di Desa Batanjung Kabupaten Kapuas adalah:

1. Implementasi program yang responsif dan sensitif gender, karena perempuan nelayan Kapuas terlibat aktif dalam penangkapan. Dengan memberikan kesempatan pada perempuan untuk menjadi anggota kelompok nelayan.

2. Program-program pembangunan ke depan perlu menyediakan kesempatan kepada wanita nelayan untuk memiliki peluang untuk mengembangkan kemampuan dirinya yang setara dengan pria. Misalnya melalui integrasi kebijakan pembangunan dan pemberdayaan perempuan ke dalam kebijakan nasional, propinsi atau kabupaten/kota baik pada ranah perencanaan, pelaksanaan, pemantauan maupun evaluasi pembangunan. Upaya ini tidaklah mudah dilakukan jika tidak didukung adanya kesadaran dan kepekaan para pengambil kebijakan tentang kesetaraan dan keadilan gender yang diikuti oleh programprogram yang dapat menjamin keterlibatan para wanita.

3. Peningkatan kualitas SDM nelayan melalui pelatihan, keterampilan, manajemen usaha, kewirausahaan dan akses terhadap mutu produk perikanan perlu mendapatkan prioritas dari pemerintah.

4. Adanya akses modal yang sensitif gender untuk usaha yang dilakukan, serta adanya monitoring dan evaluasi terhadap penerapan keterampilan dalam bentuk usaha oleh pendamping dari instansi terkait.

\section{DAFTAR PUSTAKA}

Hubies, A.V.S. Masalah Jender. Makalah di sampaikan dalam acara Lokakraya EXPERT dan UMA-BUILD, diselenggarakan oleh UNDP/UNCHS, Jakarta, 28- 30 Juni 2000.

Kementerian Pemberdayaan Perempuan, 2002. Panduan Pelaksanaan Inpres Nomor 9 Tahun 2000 Tentang Pengarusutamaan Gender Dalam Pembangunan Nasional. Edisi II.

Kusnadi, 2001. Pangamba. Kaum Perempuan Fenomenal, Pelopor dan Penggerak Perekonomian Masyarakat Nelayan. Humaniora Utama Press. Bandung.

Miles dan Hubeman, 1992. Analisis Data Kualitatif: Buku Sumber tentang Metodemetode Baru. UI Press. Jakarta.

Saruan, 2000. Studi Gender Pada Rumah Tangga Nelayan dalam Pengelolaan Sumberdaya pesisir dan Lautan. Bogor. Tesis Program Pascasarjana. IPB. Bogor. (unpublished). 
Sitorus,1998. Penelitian Kualitatif. Suatu Pendekatan. Bogor. Laboratorium Sosiologi, Antropologi dan Kependudukan. Jurusan IImu-ilmu Sosial dan Ekonomi Pertanian. Fakultas Pertanian Institut Pertanian Bogor.

Rahardjo, D. 1995. "Program-program Aksi untuk Mengatasi Kemiskinan dan
Kesejahteraan pada PJP II". Dalam Awan Setya Dewanta dkk. (editor), Kemiskinan dan Kesenjangan di Indonesia. Aditya Media.Yogyakarta.

Yin, R. K. 2002. Studi Kasus: Desain dan Metoda. Raja Grafindo Persada.Jakarta. 